\title{
Effects of some cooking methods and some treatments on the concentrations of heavy metals in meats
}

Dina H.EL Bushuty* and Naglaa M. Shanshan*

*Home Economics Dept., Fac. Specific Education, Damietta Univ., Egypt.

\section{INTRODUCTION}

Meat is an essential part of the food we eat and consists mainly of protein and fats and some important basic elements (Akan et al.,2010). It is a very rich and an important source of nutrient, including micronutrients. The chemical composition of meat relies on both the type and degree of the feeding animal. Metals can be classified as toxic (cadmium, mercury) and essential (cobalt, copper, zinc, iron) (Munoz-Olives et al.,2001).

Meat has the ability to accumulate toxic minerals and is an important source of heavy metals for human consumption that is dangerous to animal and human health. (Aycicek et al., 2008). Animal diet and contaminated environment in which animal respire is responsible for heavy metal pollution in meat (Jalil, 2013).Heavy metals are series of toxic chemicals, constant in the environment, bio-accumulative and non biodegradable in food series(Uysal $\boldsymbol{e t}$ al., 2008). Not only do heavy metals have serious positive roles in human life, but also there are negative roles too. Some of the heavy metals are considered essential, and these inclusive iron, zinc, and copper, whereas some other metals such as mercury, cadmium, lead, and arsenic have toxic roles in biochemical response of our body (Divrikli et al., 2006).

One of the main mechanisms backwards heavy metal toxicity has been attributed to oxidative stress. Toxic metals excess production of free radicals and decrease availability of antioxidant reserves to reply to the resultant damage. A growing amount of data supply evidence that metals are capable of interacting with nuclear proteins and DNA causing oxidative of biological devolution macromolecules (Leonard et al., 2004).It is well known that heavy metals induce toxic effects on various systems and apparatuses. Moreover, because of their long half-life, heavy metals also induce collection phenomena, which in turn make an experimental excess of their concentration in blood and tissues. Besides their effects and their inclusion in chronic respiratory disease, there is a danger that heavy metals intoxication may lead to damage of the nervous system (Mameli et al., 2001).

The meat is often sold each as fresh (whole undressed) carcasses, or dressed and smoked. Most people use diverse cooking methods to treat these meats and these methods contain barbequing, boiling, grilling, pan frying, stir frying and 
roasting which is done to excess its flavor, taste, palatability and to turn out it tender(Barnes, 1994 and Omojola et al.,2015).

The cooking experiments showed that heat treatment had diverse effects on the different nutrients. The determining agents for the changes were the meat cut itself as well as the parameters related to the identical cooking methods applied (time, medium and temperature) (Gerber, 2007).However, with the different cooking methods and their effects on palatability, there is a poverty of information on the impact on different cooking methods on heavy metals concentration in animal meat (Joyce et al., 2016). Dietary supplements have been reported to play significant roles in the reduction or prevention of $\mathrm{Cd}$ and $\mathrm{Pb}$ toxicity. Dietary strategies are helpful, as nutritional ingredients can easily and affordably be added to the daily food and can beat the negative side effects of the chelating therapy (Zhai et al., 2015). Therefore, the purpose of this study was to estimate some heavy metals such as $\mathrm{Pb}, \mathrm{Hg}, \mathrm{Cd}, \mathrm{Ni}, \mathrm{Cu}$ and $\mathrm{Co}$ in fresh meats (btello . kndoz and danni), also to investigate the effects of cooking methods boiling and frying on these heavy metals and to study the protective effect of soaking fresh meats precooking in natural foods (tomato juice, lemon juice, onion juice and yogurt) on these heavy metals concentration.

\section{MATERIALS AND METHODS \\ Sample Collection and Preparation}

This study was conducted in Faculty of Science, Damietta University. A total of (330 ) samples of fresh meats (Btello " small veal", Kndoz "beef" and Danni "sheep")were collected randomly from local markets of some villages in Damietta Governorate (El Sananya, El Basarta, EL Adlya, El Bustan and El Brashya), Egypt. Meat samples were collected from ten different local markets to supply replicate samples of every meat. According to their kinds, all collected samples were stored in clean polythene bags and brought to the laboratory for preparation and processing . All samples were stored at $-10^{\circ} \mathrm{C}$ until analysis (Parekhan et al., 2014).

\section{Samples cooking}

Fresh meat samples were ready for cooking and served as the standard. Meat samples were distributed carefully to two different cooking conditions of boiling and frying. The meat was washed and boiled in a cooking pan with enough water to cover meat using gas stove as described by Omojola $\boldsymbol{e t}$ al.,(2015). 
The samples of fresh meats for frying were partially boiled for 5-8 minutes with water. No spices or food additives added. The meat was fried in a stainless steel frying pan containing cooking oil, fried for 3-5 minutes according to this size and the temperature obtained was $170^{\circ} \mathrm{C}$ after frying ( Joyce et al., 2016).

Prior being analyzed, samples of meat were placed outside to melt at a room's temperature. All samples were washed with distilled water to take off any polluted particles. Then samples were chopped to small pieces using a ceramic knife completely, mixed; weight 1-gram of meat was placed in a test tube for the analysis.

\section{Soaking samples precooking}

Fresh meat samples were soaked in (100\%tomato juice , $100 \%$ lemon juice, $100 \%$ onion juice and 100\%yogurt each separately) for two hours at room temperature and washed well precooking.

\section{Samples analysis for heavy metals}

A known weight of meat samples (50gm for each sample), placed in small Erienmeyer flasks, dried in an oven at $105 \mathrm{C}^{0}$ for about $24 \mathrm{~h}$, and acid digested by nitric acid and perchloric acid (2:1) on a hotplate until the solution turn into clear. Lead "Pb", Mercury "Hg", Copper "Cu" ,Cobalt "Co", Cadmium "Cd" and Nickel "Ni" concentration in the meat samples were prepared for heavy metal analysis according to the method described by Kalay et al., (1999) using an atomic absorption spectrophotometer (Pin AAcie 500,Perkin Elmer).

A total of 330 random samples were selected of fresh meats(btello . kndoz and danni ) from the local markets in some villages of Damietta governorate (110 samples ) of each type of meats to evaluate their content of $\mathrm{Pb}, \mathrm{Hg}, \mathrm{Cd}, \mathrm{Cu}, \mathrm{Ni}$ and Co. The samples of each kind of meats were divided as follows:

Group 1: contains 10 samples of fresh meats.

Group 2: contains 10 samples that were just boiled

Group 3: contains 10 samples that were just fried

Group4: contains 10 samples soaked in $100 \%$ tomato juice for 2 hours before boiling

Group 5: contains 10 samples soaked in $100 \%$ lemon juice for 2 hours before boiling

Group 6: contains 10 samples soaked in $100 \%$ onion juice for 2 hours before boiling 
Group 7: contains 10 samples soaked in $100 \%$ yogurt for 2 hours before boiling Group8: contains 10 samples soaked in $100 \%$ tomato juice for 2 hours before frying

Group 9: contains 10 samples soaked in $100 \%$ lemon juice for 2 hours before frying

Group10: contains 10 samples soaked in $100 \%$ onion juice for 2 hours before frying

Group 11: contains 10 samples soaked in 100\%yogurt for 2 hours before frying

\section{Statistical Analysis:}

Statistical analysis were performed by using computer of statistical package for social science (SPSS version 11.0 ). The results are presented as means $\underline{ \pm}$ SD (SPSS,1999).

\section{RESULTS AND DISCUSSION}

\section{Heavy metals concentrations in fresh meats}

Data in table (1) demonstrated the heavy metals concentration in fresh meats btello, kndoz and danni . Cadmium are most commonly distributed ecological metal poisons and each of these constant contaminants has been blamed for large-scale poisoning agents (Anonymous, 2003). Concerning $\mathrm{Cd}$ concentration the results showed significant differences between fresh Btello samples and other samples ( fresh kndoz and fresh danni). The highest concentration of $\mathrm{Cd}$ was found in btello meat $(0.82 \pm 0.02 \mathrm{ppm})$ and the lowest concentration of $\mathrm{Cd}$ was found in danni meat which was $(0.38 \pm 0.03 \mathrm{ppm})$.It was found that these values appeared lower than the maximum $\mathrm{Cd}$ level allowed $2 \mathrm{ppm}$ by Choi (2011). Whereas the concentrations of $\mathrm{Hg}$ and $\mathrm{Pb}$ were non detectable. $\mathrm{Cu}$ is a primary component of various enzymes and it plays a key part in bone constructional, skeletal mineralization and in maintaining the safety of the connective tissues. $\mathrm{Cu}$ is fund a mental for good health, but very high intake can cause health problems such as liver and kidney injury (Atsdr, 2004). For $\mathrm{Cu}$ concentrations the results in table (1) declared significant decrease in $\mathrm{Cu}$ concentrations in kndoz and danni meat samples comparing to Btello sampls. The $\mathrm{Cu}$ concentrations obtained from this study were $(1.62 \pm$ $0.11,1.22 \pm 0.08$ and $1.22 \pm 0.10 \mathrm{ppm}$ ) for btello, kndoz and danni meats respectively ,these results were lower than those recorded by Canli and Atli (2003).In this concern, the provisional tolerable weekly intakes (PTWI) $\mathrm{Cu}$ for fresh meat has been proposed as $14 \mathrm{mg} /$ week/ person.(Food and Nutrition Board, 2001). Concerning Co concentrations the results showed significant 
differences between fresh btello meats and fresh kndoz meats while there were no significant differences between fresh btello meats and fresh danni meats. As well as the Co concentrations were high in btello meat ( $0.21 \pm 0.05 \mathrm{ppm})$ while Co concentrations were low in kndoz meat $0.16 \pm 0.04 \mathrm{ppm})$. Concerning $\mathrm{Ni}$ concentration the results showed significant differences between fresh btello samples and other samples (fresh kndoz and fresh danni meats). Although $\mathrm{Ni}$ is considered an essential element, $\mathrm{Ni}$ can cause respiratory problems and is carcinogenic (Atsdr , 2004), it was observed that the lowest $\mathrm{Ni}$ concentration was found in kndoz meat at $0.26 \pm 0.06 \mathrm{ppm}$ and the highest $\mathrm{Ni}$ concentration was found in danni meat $(0.49 \pm 0.03 \mathrm{ppm})$. These results were far below the permissible limit of $0.500 \mathrm{mg} / \mathrm{kg}$, as recorded by USDA( 2006 ).

On the other hand, the concentration of heavy metals in meat from various animals relies on factors like environmental conditions, type of grassland and industrialization development ( Kadim et al., 2013).

Table (1) heavy metals concentrations (ppm soft tissue ) in fresh meats

\begin{tabular}{|c|c|c|c|c|c|c|}
\hline $\begin{array}{l}\text { Meat } \\
\text { samples }\end{array}$ & $\begin{array}{c}\text { Cd } \\
(\text { Means } \pm \text { SD) }\end{array}$ & $\begin{array}{c}\mathrm{Hg} \\
(\text { Means } \pm \text { SD) }\end{array}$ & $\begin{array}{c}\mathrm{Pb} \\
(\text { Means } \pm \text { SD) }\end{array}$ & $\begin{array}{c}\mathrm{Cu} \\
(\mathrm{Means} \pm \underline{\mathrm{SD}})\end{array}$ & $\begin{array}{c}\text { Co } \\
(\text { Means } \pm \text { SD) }\end{array}$ & $\begin{array}{c}\mathrm{Ni} \\
(\text { Means } \pm \text { SD) }\end{array}$ \\
\hline $\begin{array}{l}\text { Fresh } \\
\text { Btello }\end{array}$ & $0.82 \pm 0.02^{\mathrm{a}}$ & ND & ND & $1.62 \pm 0.11^{a}$ & $0.21 \pm 0.05^{a}$ & $0.42 \pm 0.02^{b}$ \\
\hline $\begin{array}{l}\text { Fresh } \\
\text { Kndoz }\end{array}$ & $0.70 \pm 0.03^{b}$ & ND & ND & $1.22 \pm 0.08^{b}$ & $0.16 \pm 0.04^{b}$ & $0.26 \pm 0.06^{\mathrm{c}}$ \\
\hline $\begin{array}{l}\text { Fresh } \\
\text { Danni }\end{array}$ & $0.38 \pm 0.03^{\mathrm{c}}$ & ND & ND & $1.22 \pm 0.10^{b}$ & $0.19 \pm 0.05^{\mathrm{ab}}$ & $0.49 \pm 0.03^{a}$ \\
\hline
\end{tabular}

$\mathrm{ND}=$ non detectable, $\mathrm{ppm}=$ part per million

Different letters on same column represent statistically significant $(\mathrm{P}<0.05)$ difference between means.

\section{Effect of cooking methods (boiling - frying) on heavy metals concentrations in fresh meats}

Cooking may lower metal content although some foods can absorb metals if the cooking water is polluted. Metals used in food processing equipment or food packaging material may contribute to food pollution. Pollution may also happen during kitchen preparation and storage( Morgan, 1999).

Results presented in table (2) demonstrated the effect of cooking methods boiling and frying on heavy metals concentrations in fresh meats.

Results showed that boiling and frying of fresh meats caused significant decrease $(\mathrm{p}<0.05)$ in $\mathrm{Cd}$ concentrations comparing $\mathrm{Cd}$ concentrations of fresh meats where boiling reduced $\mathrm{Cd}$ concentrations to $0.28 \pm 0.04,0.05 \pm 0.01$ and $0.08 \pm 0.01 \mathrm{ppm}$ as well as frying of fresh meat reduced the $\mathrm{Cd}$ 
concentrations to $0.42 \pm 0.02,0.07 \pm 0.02$ and $0.18 \pm 0.01 \mathrm{ppm}$ comparing to the $\mathrm{Cd}$ concentrations in fresh meats $(0.82 \pm 0.02,0.70 \pm 0.03$ and $0.38 \pm 0.03$ ppm) in btello ,kndoz and danni meats respectively.

These results are in harmonization with Okareh and Akande (2015) who found that $\mathrm{Cd}$ were reduced in all boiled cooked samples while the increase in $\mathrm{Cd}$ concentrations may be associated with evaporation that happens during frying treatment (Diaconescu et al., 2012).

In this respect, Ersoy (2011) declared that cooking methods reduced heavy metal concentration in African catfish. and the effect of cooking methods on the level of heavy metals in fish is relies on the specific heavy metal and cooking medium. Boiling of fish prior consumption is defend for the lowering of $\mathrm{Cd}$ and $\mathrm{Pb}$ concentration in Clariasgariepinus. fish, In addition, Joyce et al.,(2016) found that cooking has the capacity to decrease the level of the most toxic heavy metal .

However, the results showed that frying declared significant decrease $(\mathrm{p}<0.05)$ in Co concentrations in btello, kndoz and danni meats comparing the concentrations of fresh meats while boiling showed significant decrease $(\mathrm{p}<0.05)$ in Co concentrations in btello and kndoz samples comparing the concentrations of fresh meats.

Co concentration in boiled samples were $(0.15 \pm 0.03,0.08 \pm 0.03$ and $0.17 \pm$ $0.01 \mathrm{ppm})$ and in fried samples were $(0.14 \pm 0.03,0.07 \pm 0.03$ and $0.16 \pm 0.01$ $\mathrm{ppm})$ these concentrations were lower than that of the fresh meats $(0.21 \pm 0.05$ , $0.16 \pm 0.04$ and $0.19 \pm 0.05 \mathrm{ppm}$ ) in btello ,kndoz and danni meats respectively . In this concern Ajani et al.,(2013) attributed to heat effect on heavy metals and a potential of the heavy metal being turn into other compounds. It was also reported that cooking methods (boiling, steaming, frying and others) can change the concentration of toxic metals through different means, including the evaporation of water and volatile components, solublization of the element and also by metal binding to other macronutrients existing in the food items like carbohydrates, lipids and proteins.

Moreover, the concentrations of $\mathrm{Ni}$ for all boiled and fried danni samples meats in table ( 2 ) showed significantly decrease compared to that of fresh meat samples while, fried btello and fried kndoz meat samples showed no significant differences in the Ni concentrations between these samples and that of fresh meats . 
In this concern Ersoy (2011) reported that heavy metal level in meats can be affected by processing or cooking methods.

Therefore, the results showed significant increase in $\mathrm{Cu}$ concentrations after boiling to become $1.82 \pm 0.02,1.48 \pm 0.04$ and $1.64 \pm 0.03 \mathrm{ppm}$ in boiled samples in btello, kndoz and danni meats respectively while, the results also declared that frying caused significant decrease in $\mathrm{Cu}$ concentrations in fried btello and fried danni meat samples. Frying decreased $\mathrm{Cu}$ concentrations to $1.50 \pm 0.04,1.18 \pm 0.03$ and $1.16 \pm 0.02 \mathrm{ppm}$ in fried samples in btello ,kndoz and danni meats respectively. These results are in agreement with Joyce $\boldsymbol{e t}$ al.,(2016) who declared that boiling increased $\mathrm{Cu}$ level but frying decreased $\mathrm{Cu}$ level in meats.

In this respect ,Gerber (2007) cooking heat affects meats, it will lose some water due to evaporation and drip loss ,also affects the minerals concentration. The amount of the losses will rely on the temperature and length of time the meats is cooked. Many studies reported that some changes happened during cooking in the $\mathrm{Cd}, \mathrm{Ni}, \mathrm{Co}$ and $\mathrm{Cu}$ levels Jorhem et al., (1994) .

On the other hand, Eboh et al.,(2006) reported that some cooking procedures could be applied for the moderate lowering of heavy metals in meats. Also, Ahmed et al.,( 2011) and Ajani et al.,(2013) attributed to the influence of heat on heavy metals and the possibility of converting the heavy metal into other compounds. It has also been mentioned that cooking methods (boiling, evaporation, frying, etc.) can change the levels of heavy metals through various ways, like water evaporation and volatile components, dissolving the element and also linking minerals to large nutrients present in food like as carbohydrates, fats and proteins.

Table (2)The effect of boiling and frying on the heavy metals concentrations (ppm soft tissue) in fresh meats.

\begin{tabular}{|c|c|c|c|c|}
\hline $\begin{array}{l}\text { Elements } \\
\text { Meat samples }\end{array}$ & $\begin{array}{c}\mathbf{C d} \\
(\text { Means } \pm \text { SD })\end{array}$ & $\underset{(\text { Means } \pm \text { SD })}{\mathbf{C u}}$ & $\begin{array}{c}\text { Co } \\
(\text { Means } \pm \text { SD })\end{array}$ & $\underset{(\text { Means } \pm \text { SD })}{\mathbf{N i}}$ \\
\hline $\begin{array}{l}\text { Fresh Btello } \\
\end{array}$ & $0.82 \pm 0.02^{\mathrm{a}}$ & $1.62 \pm 0.11^{b}$ & $0.21 \pm 0.05^{\mathrm{a}}$ & $0.42+0.02^{\mathrm{a}}$ \\
\hline Boiled Btello & $0.28 \pm 0.04^{\mathrm{c}}$ & $1.82 \pm 0.02^{\mathrm{a}}$ & $0.15 \pm 0.03^{b}$ & $0.24 \pm 0.03^{b}$ \\
\hline Fried Btello & $0.42 \pm 0.02^{\mathrm{b}}$ & $1.50 \pm 0.04^{\mathrm{c}}$ & $0.14 \pm 0.03^{b}$ & $0.44 \pm 0.03^{\mathrm{a}}$ \\
\hline Fresh Kndoz & $0.70 \pm 0.03^{\mathrm{a}}$ & $1.22 \pm 0.08^{b}$ & $0.16 \pm 0.04^{\mathrm{a}}$ & $0.26 \pm 0.06^{\mathrm{a}}$ \\
\hline Boiled kndoz & $0.05 \pm 0.01^{\mathrm{c}}$ & $1.48 \pm 0.04^{\mathrm{a}}$ & $0.08 \pm 0.03^{b}$ & $0.21 \pm 0.03^{b}$ \\
\hline Fried Kndoz & $0.07 \pm 0.02^{b}$ & $1.18 \pm 0.03^{b}$ & $0.07 \pm 0.03^{b}$ & $0.27 \pm 0.02^{\mathrm{a}}$ \\
\hline Fresh Danni & $0.38+0.03^{\mathrm{a}}$ & $1.22+0.10^{b}$ & $0.19+0.05^{\mathrm{a}}$ & $0.49+0.03^{\mathrm{a}}$ \\
\hline Boiled Danni & $0.08 \pm 0.01^{c}$ & $1.64 \pm 0.03^{a}$ & $0.17 \pm 0.01^{\text {ba }}$ & $0.25 \pm 0.03^{\mathrm{c}}$ \\
\hline Fried Danni & $0.18+0.01^{b}$ & $1.16+0.02^{c}$ & $0.16+0.01^{b}$ & $0.28+0.03^{b}$ \\
\hline
\end{tabular}

ppm = part per million

Different letters on same column represent statistically significant $(\mathrm{P}<0.05)$

difference between means. 


\section{Effect of some treatments on the heavy metals concentrations in meats \\ The effect of soaking fresh meats before boiling in tomato juice on the heavy metals concentrations}

Data in table (3) demonstrated the effect of soaking fresh meats in tomato juice on the heavy metals concentrations (ppm soft tissue ) in boiled meats Results in this table showed that boiled meats soaked in tomato juice reduced the Cd concentrations to $0.09 \pm 0.03$, ND and ND ppm comparing to the boiled meats $(0.28 \pm 0.04,0.05 \pm 0.01$ and $0.08 \pm 0.01 \mathrm{ppm})$ in btello ,kndoz and danni meats respectively.

On the other hand, boiled meats soaked in tomato juice reduced each of $\mathrm{Cu}$ concentrations to $1.50 \pm 0.03,1.17 \pm 0.02$ and $1.36 \pm 0.04 \mathrm{ppm}$, Co concentration to $0.08 \pm 0.03$, ND and $0.03 \pm 0.01 \mathrm{ppm}$ and $\mathrm{Ni}$ concentration to $0.13 \pm 0.02$, $0.11 \pm 0.03$ and $0.08 \pm 0.02 \mathrm{ppm}$ comparing to the boiled meat samples in btello ,kndoz and danni meats respectively.

In this concern, Ilić et al.,(2014) reported that tomato as a fruit vegetable is not distinguished by high accumulation of heavy metals. The authors found important greater concentrations of $\mathrm{Cu}$, and $\mathrm{Ni}$ in conventional tomatoes, but we found the growing method to have no influence on $\mathrm{Cd}$ and $\mathrm{Cu}$ concentrations in all cultivars.

In this respect, Monachese et al.,(2012) stated that tomatoes are rich in (iron, calcium, selenium, zinc, vitamins B and C, quercetin and naringenin), as well as particularly important as natural antagonists to $\mathrm{Cd}$ and $\mathrm{Pb}$ toxicity and should be consumed regularly.

Moreover, Shi and Maguer(2000) declared that tomato is considered as one of the most potent natural antioxidants. Also, tomato has been reported to make metal chelating proteins and phytochelatins when exposed to heavy metal ions (Tito et al., 2011). 
Table (3) The effect of soaking fresh meats before boiling in tomato juice on the heavy metals concentrations (ppm soft tissue )

\begin{tabular}{|c|c|c|c|c|}
\hline $\begin{array}{ll} & \text { Elements } \\
\text { Meat samples } & \end{array}$ & $\begin{array}{c}\text { Cd } \\
(\text { Means } \pm \text { SD })\end{array}$ & $\begin{array}{c}\mathrm{Cu} \\
(\mathrm{Means} \pm \mathrm{SD})\end{array}$ & $\begin{array}{c}\text { Co } \\
(\text { Means } \pm \text { SD) }\end{array}$ & $\begin{array}{c}\mathrm{Ni} \\
(\text { Means } \pm \text { SD })\end{array}$ \\
\hline $\begin{array}{l}\text { Boiled Btello } \\
\text { Boiled Btelo processed with } \\
\text { tomato juice }\end{array}$ & $\begin{array}{l}0.28 \pm 0.04 \\
0.09 \pm 0.03\end{array}$ & $\begin{array}{l}1.82 \pm 0.02 \\
1.50 \pm 0.03\end{array}$ & $\begin{array}{l}0.15 \pm 0.03 \\
0.08 \pm 0.03\end{array}$ & $\begin{array}{l}0.24 \pm 0.03 \\
0.13 \pm 0.02\end{array}$ \\
\hline $\begin{array}{l}\text { Boiled Kndoz } \\
\text { Boiled kndoz processed with } \\
\text { tomato juice }\end{array}$ & $\begin{array}{c}0.05 \pm 0.01 \\
\text { ND }\end{array}$ & $\begin{array}{l}1.48 \pm 0.04 \\
1.17 \pm 0.02\end{array}$ & $\begin{array}{c}0.08 \pm 0.03 \\
\text { ND }\end{array}$ & $\begin{array}{l}0.21 \pm 0.03 \\
0.11 \pm 0.03\end{array}$ \\
\hline $\begin{array}{l}\text { Boiled Danni } \\
\text { Boiled Danni meat processed } \\
\text { with tomato juice }\end{array}$ & $\begin{array}{c}0.08 \pm 0.01 \\
\text { ND }\end{array}$ & $\begin{array}{l}1.64 \pm 0.03 \\
1.36 \pm 0.04\end{array}$ & $\begin{array}{l}0.17 \pm 0.01 \\
0.03 \pm 0.01\end{array}$ & $\begin{array}{l}0.25 \pm 0.03 \\
0.08 \pm 0.02\end{array}$ \\
\hline
\end{tabular}

$\mathrm{ND}=$ non detectable, $\mathrm{ppm}=$ part per million

\section{The effect of soaking fresh meats before frying in tomato juice on the heavy metals concentrations}

Data in table (4) demonstrated the effect of soaking fresh meats in tomato juice on the heavy metals concentrations (ppm soft tissue ) in fried meats

According to the results in table (4) the mean concentrations of $\mathrm{Cd}, \mathrm{Cu}, \mathrm{Co}$ and $\mathrm{Ni}$ were decreased in fried meat samples processed with tomato juice to become $(0.12 \pm 0.02, \mathrm{ND}$ and $0.05 \pm 0.01 \mathrm{ppm}$ for $\mathrm{Cd}),(1.28 \pm 0.06,1.05 \pm 0.03$ and $0.95 \pm 0.01 \mathrm{ppm}$ for $\mathrm{Cu}),(\mathrm{ND}, \mathrm{ND}$ and ND ppm for Co) and $(0.15 \pm 0.04, \mathrm{ND}$ and ND $\mathrm{ppm}$ for Ni ) comparing to the mean concentrations of $\mathrm{Cd}, \mathrm{Cu}, \mathrm{Co}$ and $\mathrm{Ni}$ in fried meats in btello, kndoz and danni meats respectively.

These results are in concordance with that obtained by Nwokocha et al., (2012) who indicated that tomato has been shown to significantly decrease the accumulation of heavy metals in the tissues.

Table (4) The effect of soaking fresh meats before frying in tomato juice on the heavy metals concentrations (ppm soft tissue )

\begin{tabular}{|c|c|c|c|c|}
\hline $\begin{array}{ll} & \text { Elements } \\
\text { Meat samples } & \\
\end{array}$ & $\begin{array}{c}\text { Cd } \\
(\text { Means } \pm \text { SD })\end{array}$ & $\begin{array}{c}\mathrm{Cu} \\
(\text { Means } \pm \text { SD) }\end{array}$ & $\begin{array}{c}\text { Co } \\
(\text { Means } \pm \text { SD) }\end{array}$ & $\begin{array}{c}\mathrm{Ni} \\
(\text { Means } \pm \text { SD })\end{array}$ \\
\hline $\begin{array}{l}\text { Fried Btello } \\
\text { Fried Btelo processed with } \\
\text { tomato juice }\end{array}$ & $\begin{array}{l}0.42 \pm 0.02 \\
0.12 \pm 0.02\end{array}$ & $\begin{array}{l}1.50 \pm 0.04 \\
1.28 \pm 0.06\end{array}$ & $\begin{array}{c}0.14 \pm 0.03 \\
\text { ND }\end{array}$ & $\begin{array}{l}0.44 \pm 0.03 \\
0.15 \pm 0.04\end{array}$ \\
\hline $\begin{array}{l}\text { Fried Kndoz } \\
\text { Fried Kndoz processed } \\
\text { with tomato juice }\end{array}$ & $\begin{array}{c}0.07 \pm 0.02 \\
\mathrm{ND}\end{array}$ & $\begin{array}{l}1.18 \pm 0.03 \\
1.05 \pm 0.03\end{array}$ & $\begin{array}{c}0.07 \pm 0.03 \\
\mathrm{ND}\end{array}$ & $\begin{array}{c}0.27 \pm 0.02 \\
\mathrm{ND}\end{array}$ \\
\hline $\begin{array}{l}\text { Fried Danni } \\
\text { Fried Danni processed } \\
\text { with tomato juice }\end{array}$ & $\begin{array}{l}0.18 \pm 0.01 \\
0.05 \pm 0.01\end{array}$ & $\begin{array}{l}1.16 \pm 0.02 \\
0.95 \pm 0.01\end{array}$ & $\begin{array}{c}0.16 \pm 0.01 \\
\text { ND }\end{array}$ & $\begin{array}{c}0.28 \pm 0.03 \\
\mathrm{ND}\end{array}$ \\
\hline
\end{tabular}

$\mathrm{ND}=$ non detectable, $\mathrm{ppm}=$ part per million 


\section{The effect of soaking fresh meats before boiling in lemon juice on the heavy metals concentrations}

Data in table (5) showed that mean concentrations of heavy metals $\mathrm{Cd}, \mathrm{Cu}, \mathrm{Co}$ and $\mathrm{Ni}$ in boiled meats processed with lemon juice in btello ,kndoz and danni meats respectively, were reduced compared to mean concentrations of these heavy metals in boiled meats in btello, kndoz and danni meats respectively. $\mathrm{Cd}$ concentrations of meat samples soaked in lemon juice were $0.11 \pm 0.03$, ND and ND ppm, whereas $\mathrm{Cu}$ concentrations of meat samples soaked in lemon juice were $1.27 \pm 0.04,1.15 \pm 0.03$ and $1.12 \pm 0.03 \mathrm{ppm}$, also Co concentrations of meat samples soaked in lemon juice were ND, ND, ND ppm and $\mathrm{Ni}$ concentrations of meat samples soaked in lemon juice were $0.05 \pm 0.03$, ND and ND ppm in btello, kndoz and danni meats respectively.

Table (5) The effect of soaking fresh meats before boiling in lemon juice on the heavy metals concentrations (ppm soft tissue)

\begin{tabular}{|c|c|c|c|c|}
\hline $\begin{array}{ll}\text { Meat samples } & \text { Elements } \\
\end{array}$ & $\begin{array}{c}\text { Cd } \\
(\text { Means } \pm \text { SD })\end{array}$ & $\begin{array}{c}\mathrm{Cu} \\
(\text { Means } \pm \text { SD })\end{array}$ & $\begin{array}{c}\text { Co } \\
(\text { Means } \pm \text { SD) }\end{array}$ & $\begin{array}{c}\mathbf{N i} \\
(\text { Means } \pm \text { SD })\end{array}$ \\
\hline $\begin{array}{l}\text { Boiled Btello } \\
\text { Boiled Btelo processed } \\
\text { with lemon juice }\end{array}$ & $\begin{array}{l}0.28 \pm 0.04 \\
0.11 \pm 0.03\end{array}$ & $\begin{array}{l}1.82 \pm 0.02 \\
1.27 \pm 0.04\end{array}$ & $\begin{array}{c}0.15 \pm 0.03 \\
\text { ND }\end{array}$ & $\begin{array}{l}0.24 \pm 0.03 \\
0.05 \pm 0.03\end{array}$ \\
\hline $\begin{array}{l}\text { Boiled Kndoz } \\
\text { Boiled Kndoz processed } \\
\text { with lemon juice }\end{array}$ & $\begin{array}{c}\mathbf{0 . 0 5} \pm \mathbf{0 . 0 1} \\
\text { ND }\end{array}$ & $\begin{array}{l}1.48 \pm 0.04 \\
1.15 \pm 0.03\end{array}$ & $\begin{array}{c}\mathbf{0 . 0 8} \pm \mathbf{\pm 0 . 0 3} \\
\text { ND }\end{array}$ & $\begin{array}{c}0.21 \pm \mathbf{0 . 0 3} \\
\text { ND }\end{array}$ \\
\hline $\begin{array}{l}\text { Boiled Danni } \\
\text { Boiled Danni processed } \\
\text { with lemon juice }\end{array}$ & $\begin{array}{c}0.08 \pm 0.01 \\
\text { ND }\end{array}$ & $\begin{array}{l}1.64 \pm 0.03 \\
1.12 \pm 0.03\end{array}$ & $\begin{array}{c}0.17 \pm 0.01 \\
\text { ND }\end{array}$ & $\begin{array}{c}0.25 \pm 0.03 \\
\text { ND }\end{array}$ \\
\hline
\end{tabular}

$\mathrm{ND}=$ non detectable, $\mathrm{ppm}=$ part per million

The effect of soaking fresh meats before frying in lemon juice on the heavy metals concentrations

Results presented in table (6) demonstrated the effect of soaking fresh meats in lemon juice on the heavy metals concentrations (ppm soft tissue ) in fried meats

According to the results in table (6) the mean concentrations of $\mathrm{Cd}, \mathrm{Cu}, \mathrm{Co}$ and $\mathrm{Ni}$ decreased in fried meat samples processed with lemon juice to become $0.17 \pm 0.02, \mathrm{ND}$ and $\mathrm{ND}$ ppm for $\mathrm{Cd}, 1.22 \pm 0.03,0.87 \pm 0.03$ and $0.69 \pm 0.03$ ppm for $\mathrm{Cu}, 0.06 \pm 0.02$, ND and ND ppm for Co and $0.20 \pm 0.04$, ND and ND ppm for $\mathrm{Ni}$ when compared to the mean concentrations of $\mathrm{Cd}, \mathrm{Cu}, \mathrm{Co}$ and $\mathrm{Ni}$ concentrations in fried meat samples in btello ,kndoz and danni meats respectively.

Results from tables $(5,6)$ are in a concordance with that obtained by Shalan $\boldsymbol{e t}$ al.,(2005) who found that lemon contains vitamin C (ascorbic acid) which reduce the toxic effect of heavy metals. In this regard dietary vitamin $\mathrm{C}$ supplementation can be considered as effective antioxidant against toxic effects of heavy metals Sahiti et al.,(2018). 
Table (6) The effect of soaking fresh meats before frying in lemon juice on the heavy metals concentrations (ppm soft tissue )

\begin{tabular}{|c|c|c|c|c|}
\hline $\begin{array}{ll}\text { Meat samples } & \text { Elements } \\
\end{array}$ & $\begin{array}{c}\text { Cd } \\
(\text { Means } \pm \text { SD })\end{array}$ & $\begin{array}{c}\mathrm{Cu} \\
(\mathrm{Means} \pm \mathrm{SD})\end{array}$ & $\begin{array}{c}\text { Co } \\
(\text { Means } \pm \text { SD })\end{array}$ & $\begin{array}{c}\mathrm{Ni} \\
(\text { Means } \pm \text { SD) }\end{array}$ \\
\hline $\begin{array}{l}\text { Fried Btello } \\
\text { Fried Btelol processed } \\
\text { with lemon juice }\end{array}$ & $\begin{array}{l}0.42 \pm 0.02 \\
0.17 \pm 0.02\end{array}$ & $\begin{array}{l}1.50 \pm 0.04 \\
1.22 \pm 0.03\end{array}$ & $\begin{array}{l}0.14 \pm 0.03 \\
0.06 \pm 0.02\end{array}$ & $\begin{array}{l}0.44 \pm 0.03 \\
0.20 \pm 0.04\end{array}$ \\
\hline $\begin{array}{l}\text { Fried Kndoz } \\
\text { Fried Kndoz processed } \\
\text { with lemon juice }\end{array}$ & $\begin{array}{c}0.07 \pm 0.02 \\
\mathrm{ND}\end{array}$ & $\begin{array}{l}1.18 \pm 0.03 \\
0.87 \pm 0.03\end{array}$ & $\begin{array}{c}0.07 \pm 0.03 \\
\text { ND }\end{array}$ & $\begin{array}{c}0.27 \pm 0.02 \\
\mathrm{ND}\end{array}$ \\
\hline $\begin{array}{l}\text { Fried Danni } \\
\text { Fried Danni processed } \\
\text { with lemon juice }\end{array}$ & $\begin{array}{c}0.18 \pm 0.01 \\
\text { ND }\end{array}$ & $\begin{array}{l}1.16 \pm 0.02 \\
0.69 \pm 0.03\end{array}$ & $\begin{array}{c}0.16 \pm 0.01 \\
\mathrm{ND}\end{array}$ & $\begin{array}{c}0.28 \pm 0.03 \\
\mathrm{ND}\end{array}$ \\
\hline
\end{tabular}

$\mathrm{ND}=$ non detectable, $\mathrm{ppm}=$ part per million

\section{The effect of soaking fresh meats before boiling in onion juice on the heavy metals concentrations}

Results presented in tables (7) revealed the effect of soaking fresh meats in onion juice on the heavy metals concentrations (ppm soft tissue ) in boiled meats

From table (7) it was observed that the mean concentrations of heavy metals $\mathrm{Cd}, \mathrm{Cu}, \mathrm{Co}$ and $\mathrm{Ni}$ decreased in boiled meats samples processed with onion juice to become $0.13 \pm 0.03$, ND and ND ppm for $\mathrm{Cd}, 1.57 \pm 0.05,1.15 \pm 0.04$ and $1.23 \pm 0.02 \mathrm{ppm}$ for $\mathrm{Cu}, 0.07 \pm 0.03$, ND and ND ppm for Co and $0.15 \pm 0.05$, $0.09 \pm 0.04$ and $0.09 \pm 0.03 \mathrm{ppm}$ for $\mathrm{Ni}$ comparing to the mean concentrations of $\mathrm{Cd}, \mathrm{Cu}, \mathrm{Co}$ and $\mathrm{Ni}$ in boiled meats in btello, kndoz and danni meats respectively.

In this respect, onion have comparable antioxidant capacities to garlic, and supplementation with these food ingredients gave protection against developmental toxicity of heavy metals (Ola-Mudathir et al., 2008).

Table (7) The effect of soaking fresh meats before boiling in onion juice on the heavy metals concentrations (ppm soft tissue)

\begin{tabular}{|c|c|c|c|c|}
\hline $\begin{array}{ll}\text { Meat samples } & \text { Elements } \\
\end{array}$ & $\begin{array}{c}\text { Cd } \\
(\text { Means } \pm \text { SD })\end{array}$ & $\begin{array}{c}\mathrm{Cu} \\
(\text { Means } \pm \text { SD) }\end{array}$ & $\begin{array}{c}\text { Co } \\
(\text { Means } \pm \text { SD })\end{array}$ & $\begin{array}{c}\mathbf{N i} \\
(\text { Means } \pm \text { SD })\end{array}$ \\
\hline $\begin{array}{l}\text { Boiled Btello } \\
\text { Boiled Btelo processed } \\
\text { with onion juice }\end{array}$ & $\begin{array}{l}0.28 \pm 0.04 \\
0.13 \pm 0.03\end{array}$ & $\begin{array}{l}1.82 \pm 0.02 \\
1.57 \pm 0.05\end{array}$ & $\begin{array}{l}0.15 \pm 0.03 \\
0.07 \pm 0.03\end{array}$ & $\begin{array}{l}0.24 \pm 0.03 \\
0.15 \pm 0.05\end{array}$ \\
\hline $\begin{array}{l}\text { Boiled kndoz } \\
\text { Boiled kndoz processed } \\
\text { with onion juice }\end{array}$ & $\begin{array}{c}0.05 \pm 0.01 \\
\text { ND }\end{array}$ & $\begin{array}{l}1.48 \pm 0.04 \\
1.15 \pm 0.04\end{array}$ & $\begin{array}{c}0.08 \pm \mathbf{\pm 0 . 0 3} \\
\mathrm{ND}\end{array}$ & $\begin{array}{l}0.21 \pm 0.03 \\
0.09 \pm 0.04\end{array}$ \\
\hline $\begin{array}{l}\text { Boiled Danni } \\
\text { Boiled Danni processed } \\
\text { with onion juice }\end{array}$ & $\begin{array}{c}0.08+0.01 \\
\text { ND }\end{array}$ & $\begin{array}{l}1.64 \pm 0.03 \\
1.23 \pm 0.02\end{array}$ & $\begin{array}{c}0.17 \pm 0.01 \\
\mathrm{ND}\end{array}$ & $\begin{array}{l}0.25 \pm 0.03 \\
0.09 \pm 0.03\end{array}$ \\
\hline
\end{tabular}

$\mathrm{ND}=$ non detectable, $\mathrm{ppm}=$ part per million 


\section{The effect of soaking fresh meats before frying in onion juice on the heavy metals concentrations}

Results presented in tables (8) demonstrated the effect of soaking fresh meats in onion juice on the heavy metals concentrations (ppm soft tissue ) in fried meats.

According to the results in table (8) it was found that the mean concentrations of $\mathrm{Cd}, \mathrm{Cu}, \mathrm{Co}$ and $\mathrm{Ni}$ decreased in fried meat samples processed with onion juice to $0.17 \pm 0.01, \mathrm{ND}$ and $0.03 \pm 0.01 \mathrm{ppm}$ for $\mathrm{Cd}, 1.23 \pm 0.02,0.87 \pm 0.05$ and $0.74 \pm 0.05 \mathrm{ppm}$ for $\mathrm{Cu}, 0.05 \pm 0.02, \mathrm{ND}$ and $0.03 \pm 0.01 \mathrm{ppm}$ for $\mathrm{Co}$ and $0.29 \pm 0.02,0.08 \pm 0.06$ and $0.10 \pm 0.03 \mathrm{ppm}$ for $\mathrm{Ni}$ when compared to the mean concentrations of $\mathrm{Cd}, \mathrm{Cu}, \mathrm{Co}$ and $\mathrm{Ni}$ concentrations in fried meat samples in btello ,kndoz and danni meats respectively.

In this concern, Monachese $\boldsymbol{e t}$ al.,(2012) reported that some edible plants like onions are good source of selenium, quercetin, vitamins B and C. Also, particularly important as natural antagonists to $\mathrm{Cd}$ and $\mathrm{Pb}$ toxicity and should be consumed regularly.

Table (8) The effect of soaking fresh meats before frying in onion juice on the heavy metals concentrations (ppm soft tissue)

\begin{tabular}{|c|c|c|c|c|}
\hline Meat samples & $\begin{array}{c}\text { Cd } \\
(\text { Means } \pm \text { SD })\end{array}$ & $\begin{array}{c}\mathrm{Cu} \\
(\mathrm{Means} \pm \text { SD })\end{array}$ & $\begin{array}{c}\text { Co } \\
(\text { Means } \pm \text { SD })\end{array}$ & $\underset{(\mathrm{Means} \pm \mathbf{S D})}{\mathbf{N i}}$ \\
\hline $\begin{array}{l}\text { Fried Btello } \\
\text { Fried Btelo processed with } \\
\text { onion juice }\end{array}$ & $\begin{array}{l}0.42 \pm 0.02 \\
0.17 \pm 0.01\end{array}$ & $\begin{array}{l}1.50 \pm 0.04 \\
1.23 \pm 0.02\end{array}$ & $\begin{array}{l}0.14 \pm 0.03 \\
0.05 \pm 0.02\end{array}$ & $\begin{array}{l}0.44 \pm 0.03 \\
0.29 \pm 0.02\end{array}$ \\
\hline $\begin{array}{l}\text { Fried Kndoz } \\
\text { Fried Kndoz processed } \\
\text { with onion juice }\end{array}$ & $\begin{array}{c}0.07 \pm 0.02 \\
\mathrm{ND}\end{array}$ & $\begin{array}{l}1.18 \pm 0.03 \\
0.87 \pm 0.05\end{array}$ & $\begin{array}{c}0.07 \pm 0.03 \\
\text { ND }\end{array}$ & $\begin{array}{l}0.27 \pm 0.02 \\
0.08 \pm 0.06\end{array}$ \\
\hline $\begin{array}{l}\text { Fried Danni } \\
\text { Fried Danni processed } \\
\text { with onion juice }\end{array}$ & $\begin{array}{l}0.18 \pm 0.01 \\
0.03 \pm 0.01\end{array}$ & $\begin{array}{l}1.16 \pm 0.02 \\
0.74 \pm 0.05\end{array}$ & $\begin{array}{l}0.16 \pm 0.01 \\
0.03 \pm 0.01\end{array}$ & $\begin{array}{l}0.28 \pm 0.03 \\
0.10 \pm 0.03\end{array}$ \\
\hline
\end{tabular}

$\mathrm{ND}=$ non detectable, $\mathrm{ppm}$, part per million

\section{The effect of soaking fresh meats before boiling in yogurt on the heavy metals concentrations}

Data in table (9) declared that mean concentrations of heavy metals $\mathrm{Cd}, \mathrm{Cu}, \mathrm{Co}$ and $\mathrm{Ni}$ in boiled meats processed with yogurt in btello ,kndoz and danni meats, were reduced compared to mean concentrations of these heavy metals in boiled meats in btello, kndoz and danni meats respectively. 
Cd concentrations of samples processed with yogurt were $0.11 \pm 0.01$, ND and $\mathrm{ND}$ ppm ,whereas $\mathrm{Cu}$ concentrations of samples processed with yogurt were $1.44 \pm 0.03,1.23 \pm 0.04$ and $1.15 \pm 0.04 \mathrm{ppm}$ also, Co concentrations of samples processed with yogurt were $0.03 \pm 0.01, \mathrm{ND}$ and ND ppm and $\mathrm{Ni}$ concentrations of samples processed with yogurt were $0.05 \pm 0.01$, ND and $0.05 \pm 0.03 \mathrm{ppm}$ in btello, kndoz and danni meats respectively.

Table (9) The effect of soaking fresh meats before boiling in yogurt on the heavy metals concentrations (ppm soft tissue )

\begin{tabular}{|c|c|c|c|c|}
\hline Meat samples & $\begin{array}{c}\text { Cd } \\
(\text { Means } \pm \text { SD })\end{array}$ & $\underset{\text { (Means } \pm \text { SD) }}{\mathbf{C u}}$ & $\begin{array}{c}\text { Co } \\
(\text { Means } \pm \text { SD })\end{array}$ & $\underset{(\text { Means } \pm \text { SD })}{\mathbf{N i}}$ \\
\hline $\begin{array}{l}\text { Boiled Btello } \\
\text { Boiled Btelo processed with } \\
\text { yogurt }\end{array}$ & $\begin{array}{l}0.28 \pm 0.04 \\
0.11 \pm 0.01\end{array}$ & $\begin{array}{l}1.82 \pm 0.02 \\
1.44 \pm 0.03\end{array}$ & $\begin{array}{c}0.15 \pm 0.03 \\
0.03 \pm 0.01\end{array}$ & $\begin{array}{l}0.24 \pm 0.03 \\
0.05 \pm 0.01\end{array}$ \\
\hline $\begin{array}{l}\text { Boiled Kndoz } \\
\text { BoiledKndoz processed with } \\
\text { yogurt }\end{array}$ & $\begin{array}{c}0.05 \pm 0.01 \\
\text { ND }\end{array}$ & $\begin{array}{l}1.48 \pm 0.04 \\
1.23 \pm 0.04\end{array}$ & $\begin{array}{c}0.08 \pm 0.03 \\
\mathrm{ND}\end{array}$ & $\begin{array}{c}0.21 \pm 0.03 \\
\text { ND }\end{array}$ \\
\hline $\begin{array}{l}\text { Boiled Danni } \\
\text { Boiled Danni processed with } \\
\text { yogurt }\end{array}$ & $\begin{array}{c}0.08 \pm 0.01 \\
\text { ND }\end{array}$ & $\begin{array}{l}1.64 \pm 0.03 \\
1.15 \pm 0.04\end{array}$ & $\begin{array}{c}0.17 \pm 0.01 \\
\text { ND }\end{array}$ & $\begin{array}{l}0.25 \pm 0.03 \\
0.05 \pm 0.03\end{array}$ \\
\hline
\end{tabular}

$\mathrm{ND}=$ non detectable, $\mathrm{ppm}=$ part per million

\section{The effect of soaking fresh meats before frying in yogurt on the heavy metals concentrations}

Results presented in table (10) demonstrated the effect of yogurt on the heavy metals concentrations (ppm soft tissue ) in fried meats.

From table (10) it was observed that the mean concentrations of heavy metals $\mathrm{Cd}, \mathrm{Cu}, \mathrm{Co}$ and $\mathrm{Ni}$ decreased in fried meat samples processed with yogurt to $0.15 \pm 0.06, \mathrm{ND}$ and ND ppm for Cd $, 1.19 \pm 0.03,0.75 \pm 0.04$ and $0.64 \pm$ $0.05 \mathrm{ppm}$ for $\mathrm{Cu}, \mathrm{ND}, \mathrm{ND}$ and ND ppm for Co and $0.17 \pm 0.03$, ND and ND ppm for $\mathrm{Ni}$ comparing to the mean concentrations of $\mathrm{Cd}, \mathrm{Cu}, \mathrm{Co}$ and $\mathrm{Ni}$ in fried meats in btello, kndoz and danni meats respectively.

The results which obtained from tables (9 and 10) are in harmonization with another study investigated the yogurt has lower effect on heavy metals concentration (Galati and O'Brien 2004).In this concern lactobacilli strain which found in yogurt has protective effect against $\mathrm{Cd}$ toxic in tissues( Tian $\boldsymbol{e t}$ al., 2012). 
Table (10) The effect of soaking fresh meats before frying in yogurt on the heavy metals concentrations (ppm soft tissue )

\begin{tabular}{|c|c|c|c|c|}
\hline Meat samples & $\underset{(\text { Means } \pm \text { SD })}{\text { Cd }}$ & $\begin{array}{c}\mathrm{Cu} \\
(\mathrm{Means} \pm \text { SD) }\end{array}$ & $\begin{array}{c}\text { Co } \\
(\text { Means } \pm \text { SD })\end{array}$ & $\underset{(\text { Means } \pm \text { SD })}{\mathbf{N i}}$ \\
\hline $\begin{array}{l}\text { Fried Btello } \\
\text { Fried Btello processed } \\
\text { with yogurt }\end{array}$ & $\begin{array}{l}0.42 \pm 0.02 \\
0.15 \pm 0.06\end{array}$ & $\begin{array}{l}1.50 \pm 0.04 \\
1.19 \pm 0.03\end{array}$ & $\begin{array}{c}0.14 \pm 0.03 \\
\text { ND }\end{array}$ & $\begin{array}{l}0.44 \pm 0.03 \\
0.17 \pm 0.03\end{array}$ \\
\hline $\begin{array}{l}\text { Fried Kndoz } \\
\text { Fried Kndoz processed } \\
\text { with yogurt }\end{array}$ & $\begin{array}{c}0.07 \pm 0.02 \\
\text { ND }\end{array}$ & $\begin{array}{l}1.18 \pm 0.03 \\
0.75 \pm 0.04\end{array}$ & $\begin{array}{c}0.07 \pm 0.03 \\
\text { ND }\end{array}$ & $\begin{array}{c}0.27 \pm 0.02 \\
\mathrm{ND}\end{array}$ \\
\hline $\begin{array}{l}\text { Fried Danni } \\
\text { Fried Danni processed } \\
\text { with yogurt }\end{array}$ & $\begin{array}{c}0.18 \pm 0.01 \\
\text { ND }\end{array}$ & $\begin{array}{l}1.16 \pm 0.02 \\
0.64 \pm 0.05\end{array}$ & $\begin{array}{c}0.16 \pm 0.01 \\
\text { ND }\end{array}$ & $\begin{array}{c}0.28+0.03 \\
\text { ND }\end{array}$ \\
\hline
\end{tabular}

$\mathrm{ND}=$ non detectable, $\mathrm{ppm}=$ part per million

\section{CONCLUSION}

Samples of fresh meats btello ,kndoz and danni which obtained from local markets from some villages in Damietta Governorate, Egypt were investigated from hevy metals. The levels of lead $(\mathrm{Pb})$ and mercury $(\mathrm{Hg})$ were non detectable .The obtained results were concluded that mostly the values of heavy metals Cadmium (Cd), Nickel (Ni), Copper $(\mathrm{Cu})$ and Cobalt $(\mathrm{Co})$ in fresh meats samples were lower than recommended maximum acceptable levels and the concentration of lead and mercury were not detectable. Cooking methods had an important effect on selected heavy metals concentrations. Boiling of fresh meats caused significant decrease $(\mathrm{p}<0.05)$ in $\mathrm{Cd}$ and $\mathrm{Ni}$ concentrations while it caused significant increase in $\mathrm{Cu}$ concentrations. On the other hand, frying of fresh meats caused significant decrease $(\mathrm{p}<0.05)$ in $\mathrm{Cd}$ and Co concentrations comparing to the concentrations of fresh meats while frying caused significant decrease in $\mathrm{Cu}$ concentrations in btello and danni meat samples .Also, it was found that soaking fresh meats (btello, kndoz and danni) precooking in natural foods (tomato juice, lemon juice, onion juice and yogurt) reduced selected heavy metals $(\mathrm{Cd}, \mathrm{Cu}, \mathrm{Co}$ and $\mathrm{Ni})$,so the present study recommends that fresh meats should be processed before cooking with the natural foods studied in order to reduce the contamination of heavy metals and overcome their health problems. 


\section{REFERENCES}

Ahmed ,A ; Dodo, A ;Bouba, A.M ; Clement ,S and Dzudie,T. (2011):Influence of traditional drying and smoke-drying on the quality of three fish species (Tilapia nilotica, Silurusglanis and Arius parkii) from Lagdo lake, Cameroon. J Anim Vet Adv.,10:301-306.

Ajani ,F; Adetuaji, V.O and Oyedokun, J.O. (2013) :Biophysiochemical changes that occur in fish during different stages of traditional processing. University of Ibadan, Nigeria,13(3).

Akan , J.C.; Abdu, F.I.; Irahman, O.A.; Sodipo, Chiroma, Y.A. (2010): Distribution of Heavy Metals in the Liver, Kidney and Meat of Beef, Mutton, Caprine and Chicken from Kasuwan Shanu Market in Maiduguri Metropolis, Borno State. Research Journal of Applied Sciences, Engineering and Technology, 2(8): 743-748.

Anonymous, 2003.Joint FAO/WHO expert committee on food additives. Sixtyfirst Meeting Rome, 10-19.

Atsdr, Z. (2004) :Agency for Toxic Substances and Disease Registry .Division of Toxicology, Clifton Road, NE, Atlanta, GA.

Aycicek, M.; Kaplan, M. and Yarman, M. (2008): Effect of cadmium on germination, seedling growth and metal contents of sunflower (Helianthus annus L). Asian J Chem, 20: 2663-2672.

Barnes, A. (1994) : A study FAO newsletter on traditional meat preservation technologies. Game animal meat drying in Ghana.5: 2-6.

Canli, M.and Atli, G.( 2003): The relationships between heavy metal $(\mathrm{Cd}, \mathrm{Cr}$, $\mathrm{Cu}, \mathrm{Fe}, \mathrm{Pb}, \mathrm{Zn}$ ) levels and the size of six Mediterranean fish species. Environmental Pollution, 121, 129-136.

Choi,Y. (2011) : International / National Standards for Heavy Metals in Food. Codex

Divrikli, U; Horzum, N; Soylak, M. and Elci, L. (2006): Trace heavy metal contents of some spices and herbal plants from Western Anatolia. Turkey, International Journal of Food Science and Technology, 41 (6): 712-716.

Diaconescu, C.; Urdes, L. ; Diaconescu, S. and Popa, D. (2012): Effects of cooking methods on the heavy metal concentrations in the fish meat originating from different areas of danube river. Scientific Papers, Animal Science, Series D, vol. LV :265- 267 
Eboh, L; Mepba, H.D and Ekpo, M.B. (2006) : Heavy metal contaminants and processing effects on the composition, storage stability and fatty acid profiles of five common commercially available fish species in Oronlocal government. Nigeria. Food Chem, 97:490-497.

Ersoy, B. (2011) : Effect of cooking methods on the heavy metal concentrations of the Africa Catfish (Clariasgariepinus). Journal of Food Biochemistry, 35(2):351-356.

Food and Nutrition Board(2001):Dietary Reference Intakes for Vitamin A, Vitamin K, Arsenic, Boron, Chromium, Copper, Iodine, Iron, Manganese, Molybdenum, Nickel, Silicon, Vanadium, and Zinc. Institute of Medicine (US) Panel on Micronutrients, National Academies Press (US).

Galati, G.and O'Brien, P.J. (2004) :Potential toxicity of flavonoids and other dietary phenolics: Significance for their chemopreventive and anticancer properties. Free Radic. Biol. Med., 37, 287-303.

Gerber, N. (2007): The role of meat in human nutrition for the supply with nutrients, particularly functional longchainn-3 fatty acids. Institut, Journal of Animal Nutrition, Nutrition Biology, ETH Zürich.

Ilić,Z ; Kapoulas,N ; Šunić,L ; Beković ,D and Mirecki3,N. (2014) : Heavy Metals and Nitrate Content in Tomato Fruit Grown in Organic and Conventional Production Systems. Pol. J. Environ. Stud.., 23 ( 6 ): 2027-2032.

Jalil, H. (2013) : Determination of Heavy Metals in Exposed Corned Beef and Chicken Luncheon That Sold in Sulaymaniah Markets. Afr J Food Sci., 7:17882.

Joyce, k; Emikpe ,B.O; Asare ,D.A; Asenso ,T.N; Richmond,Y; Jarikre, T.A and Afusat, J.J. (2016) : Effects of Different Cooking Methods on Heavy Metals Level in Fresh and Smoked Game Meat .Journal of Food Processing \& Technology,7: 617.

Jorhem,L.; Engman, J.; Sundstrom,B. and Thim,A. (1994):Trace elements in crayfish: Regional differences and changes induced by cooking. Arch. Environ. Contam. Toxicol. 26, 137-142.

Kadim, I ;Mahgoub,O; Faye, B and Farouk ,M.(2013): Camel meat and meat products.CAB International publ, Oxfordshire, UK \& Boston, USA.;248.

Kalay ,M; Ay,O and Canh, M (1999) : Heavy metal concentration in fish tissues from the northeast Mediterranean Sea . Bull. Environ. Contam. Toxicol, 63:673-681. 
Leonard, S.S.; Harris, G.K. and Shi, X.L. (2004): Metal-induced oxidative stress and signal transduction. Free Rad Biol Med; 37: 1921-42.

Mameli,O; Caria ,M.A; Solinas, A; Tavera, C; Tocco, M and Flore ,C. (2001): Neurotoxic effect of lead at low concentrations. Brain Res Bull,55(2):269-75.

Monachese, M; Burton, J.P and Reid, G.(2012) :Bioremediation and tolerance of humans to heavy metals through microbial processes: A potential role for probiotics? Appl. Environ. Microbiol, 78,6397-6404.

Morgan J.N. (1999) :Effects of Processing on Heavy Metal Content of Foods. Advances in Experimental Medicine and Biology, vol 459. Springer, Boston, MA.

Munoz -Olives, R;Camara,C: Pitts, L; Cornelis, R; Crews,H ;Donard, O.F and Quevauviller, P. (2001) :Trace element speciation for environment food and health. The Royal Society of Chemistry,PP331-353.

Nwokocha, C.R.; Nwokocha, M.I.; Aneto, I.; Obi, J.; Udekweleze, D.C.; Olatunde, B.; Owu, D.U. and Iwuala, M.O. (2012) : Comparative analysis on the effect of Lycopersiconesculentum(tomato) in reducing cadmium, mercury and lead accumulation in liver. Food Chem. Toxicol , 50, 2070-2073.

Okareh, O. T. and Akande,F. (2015) : Lead and Cadmium Levels of African Catfish (Clariasgariepinus) and the Effect of Cooking Methods on their concentrations. British Journal of Applied Science \& Technology.11(2): 1-12.

Ola-Mudathir, K.F.; Suru, S.M.; Fafunso, M.A.; Obioha, U.E. and Faremi, T.Y. (2008) : Protective roles of onion and garlic extracts on cadmium-induced changes in sperm characteristics and testicular oxidative damage in rats. Food Chem. Toxicol., 46, 3604-3611.

Omojola A.B; Ahmed, S.A;Attoh-Kotoku,V and Wogar, G.S. (2015): Effect of cooking methods on cholesterol, mineral composition and formation of total heterocyclic aromatic amines in Muscovy drake meat. J Sci Food Agric,95:98102.

Parekhan, A.; Banaz, O.R. and Dler, M.S.( 2014): Assessment of heavy metals in livers of cattle and chicken by spectroscopic method. IOSR Journal of Applied Physics (IOSR-JAP), 6 (1): 23-26.

Sahiti, H. ; Bislimi, K. ; Bajgora, A. ; Rexhepi, A. and Dalo, E. (2018): Protective Effect of Vitamin C against Oxidative Stress in Common Carp (Cyprinus Carpio) Induced by Heavy Metals. Inter J Agri Biosci, , 7(2): 71-75. 
Shalan, M.G; Mostafa,M.S; Hassouna, M.M; El-Nabi, S.E and El-Refaie, A. (2005): Amelioration of leadtoxicity on rat liver with vitamin $\mathrm{C}$ and silymarin supplements. Toxicology, 206:1-15.

Shi, J.and Maguer, M.L.(2000) : Lycopene in tomatoes: Chemical and physical properties affected by food processing. Crit. Rev. Food Sci. Nutr. 40, $1-42$.

SPSS (1999): SPSS-PC for the IBM PC/XT computer . version 11.0 SPSS Inc., U.S.A.

Tian, F.; Zhai, Q.; Zhao, J.; Liu, X.; Wang, G.; Zhang, H.; Zhang, H.and Chen, W.(2012): Lactobacillus plantarum CCFM8661 alleviates lead toxicity in mice. Biol. Trace Elem. Res., 150, 264-271.

Tito, A.; Carola, A.; Bimonte, M.; Barbulova, A.; Arciello, S.; de Laurentiis, F.; Monoli, I.; Hill, J.; Gibertoni, S. and Colucci, G. A. (2011) :tomato stem cell extract, containing antioxidant compounds and metal chelating factors, protects skin cells from heavy metal-induced damages. Int. J. Cosmet. Sci., 33, 543-552.

USDA, (2006).Foreign Agricultural Services GAIN Report; Global GAIN Report No.CH6064, Chinese People"s Republic of FAIRS products. Specific maximum levels of contaminants in foods, Jim Butterworth and Wu Bugang. PP1-60.

Uysal, K; Yılmaz ,E and Esengül ,K.(2008) : The determination of heavy metal accumulation ratios in muscle, skin and gills of some migratory fish species by inductively coupled plasma-optical emission spectrometry (ICPOES) in Beymelek Lagoon (Antalya/Turkey). Microchemical Journal.; 90:6770.

Zhai ,Q; Narbad,A and Chen, W.(2015) : Dietary Strategies for the Treatment of Cadmium and Lead Toxicity. Nutrients , 7: 552-571. 


\section{ABSTRACT \\ Effects of some cooking methods and some treatments on the concentrations of heavy metals in meats}

The aim of current study was to estimate some heavy metals like Lead "Pb" ,Mercury "Hg" ,Cadmium "Cd" Nickel "Ni" ,Copper "Cu" and Cobalt "Co" in fresh meats (Btello "small veal", Kndoz "beef" and Danni "sheep" ) also to investigate the effects of some cooking methods boiling and frying on these selected heavy metals in fresh meats, finally to investigate the protective effect of soaking fresh meats precooking in natural foods (tomato juice, lemon juice, onion juice and yogurt) on these heavy metals. A total of 330 random samples were selected of fresh meats (btello, kndoz and danni ) from the local markets of some villages in Damietta governorate(El Sananya, El Basarta, EL Adlya, El Bustan and El Brashya), 110 samples of each type of meats to evaluate their content of lead, mercury, cadmium, copper, nickel and cobalt. Where samples of each type were divided into eleven groups of equal numbers (10 samples) as follows: group 1 includes fresh samples without any treatment, groups 2 and 3 include samples treated by cooking methods (boiling and frying respectively). Groups 4,5,6 and 7 include samples which boiled and treated by soaking in $100 \%$ natural foods (tomato juice, lemon juice, onion juice and yogurt respectively) for two hours before boiling. Groups 8,9,10 and11 include samples which fried and treated by soaking in $100 \%$ natural foods (tomato juice, lemon juice, onion juice and yogurt respectively) for two hours before frying. The main results showed significant differences between fresh btello samples and other samples fresh kndoz and fresh danni in the concentrations of heavy metals $\mathrm{Cd}, \mathrm{Cu}, \mathrm{Ni}$ and the concentrations of $\mathrm{pb}, \mathrm{Hg}$ in all samples were found negligible. This indicates that the investigated samples of fresh meats btello ,kndoz and danni are safe from lead and mercury. The obtained results were concluded that mostly the values of heavy metals in fresh meats samples were lower than recommended maximum acceptable levels and the concentration of $\mathrm{Pb}$ and $\mathrm{Hg}$ were not detectable.

Results also declared that cooking methods had an important effect on these selected heavy metals concentrations. Boiling and frying of fresh meats caused significant decrease $(\mathrm{p}<0.05)$ in $\mathrm{Cd}$ concentrations comparing to the concentrations of fresh meats. However, frying of fresh meats declared 
significant decrease $(\mathrm{p}<0.05)$ in Co concentrations comparing the concentrations of fresh meats .

Moreover, the concentrations of $\mathrm{Ni}$ for all boiled meat samples and fried danni meat samples showed significantly decrease $(\mathrm{p}<0.05)$ compared to that of fresh meat samples while, fried btello and fried kndoz meat samples showed no significant differences in the $\mathrm{Ni}$ concentrations between these samples and that of fresh meats. Therefore, the results showed significant increase in $\mathrm{Cu}$ concentrations after boiling in btello ,kndoz and danni meats respectively while, the results also declared significant decrease $(\mathrm{p}<0.05)$ in $\mathrm{Cu}$ concentrations in fried btello and fried danni meat samples. In this study it was found that soaking fresh meats (btello, kndoz and danni) precooking in natural foods (tomato juice ,lemon juice, onion juice and yogurt) reduced selected heavy metals $\mathrm{Cd}, \mathrm{Cu}, \mathrm{Co}$ and $\mathrm{Ni}$.

The present study recommends that fresh meats should be processed before cooking with the natural foods studied in order to reduce the contamination of heavy metals and overcome their health problems.

Key words: meats, cooking ,cadmium, copper, cobalt, nickel, soaking ,tomato juice, lemon juice, onion juice, yogurt. 


\section{ملخص البحث}

تأثير بعض طرق الطهي ويعض المعالجات على تركيزات المعادن الثقيلة في اللحوم

يهدف البحث الحالى إلى تقدير نسب بعض المعادن الثقيلة ( الرصاص ،الزئبق ، الكادميوم ،النيكل، النحاس والكوبلت ) فى اللحوم الطازجة ( البنلو ، الكندوز والضانى) الموجودة في السوق المحلى فى لى بعض قرى محافظة دمياط ، بالإضافة إلي دراسة تأثير طرق الطهى (السلق والتحمير ) والمعالجة بيعض الأغذية الطبيعية ( عصير الطماطم ،عصير الليمون ،عصير البصل و الزبادي) على تلك

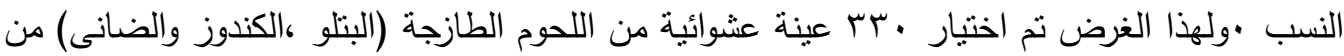
الأسواق المحلية في بعض قري محافظة دمياط ( السنانية ، البصارطة ، العدلية ، البساتين و البراثية ) بواقع · ل اعينة من كل نوع لحم حيث قسمت عينات كل نوع إلي إحدى عشر مجموعة متساوية الأعداد

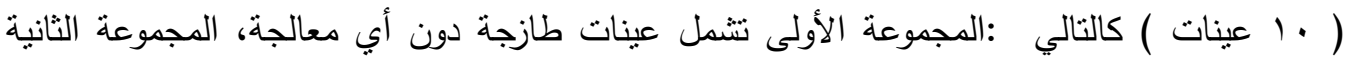

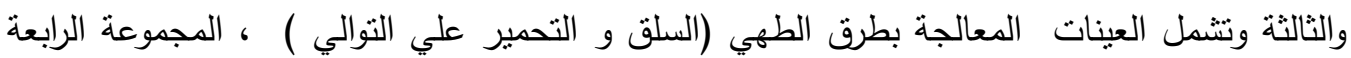

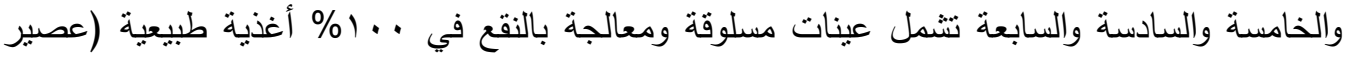
طماطم، عصير ليمون، عصبر بصل و زبادي علي التوالي ) لمدة ساعتين قبل السلق ، المجموعة

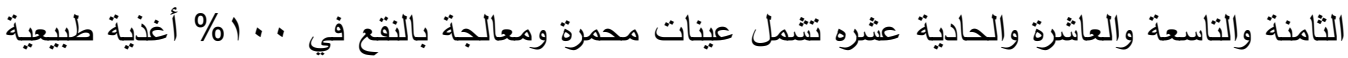
(عصير طماطم، عصبر ليمون، عصير بصل و زبادي علي التوالي ) لمدة ساعتين قبل التحمير .وقد أظهرت نتائج الدراسة أن معظم تركيزات المعادن التقبلة المدروسة في اللحوم الطازجة (البتلو ، الكندوز والضانى) كانت أقل من الحدود المسمح بها ، كما أظهرت النتائج وجود فروق معنوية(P) عينات البتلو الطازجة وعينات اللحوم الأخرى الطازجة ( الكندوز والضانى) فى نركيزات الكادميوم والنحاس والنيكل أما عنصرى الرصاص والزئيق فكانت نسبهم غير ملحوظه. كما أنشارت نتائج الدراسة التها

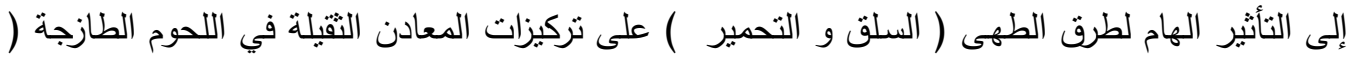
البتلو ، الكندوز والضانى) ، فبالمقارنة باللحوم الطازجة أظهر كل من السلق والتحمير انخفاض معنوى

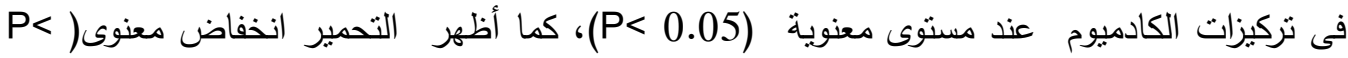
0.05) فى نركيزات الكوبلت •بالاضافة الي ظهور انخفاض معنوى (P)

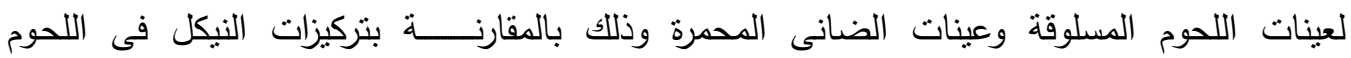

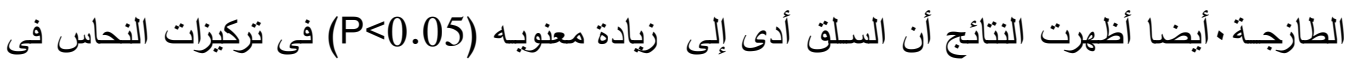

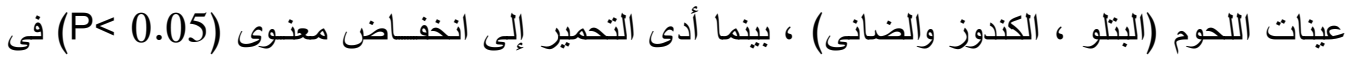

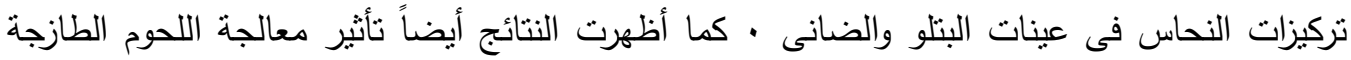


(البتلو ، الكندوز والضاني ) قبل الطهي ( السلق ، التحمير ) بالنقع في بعض الأغذية الطبيعية

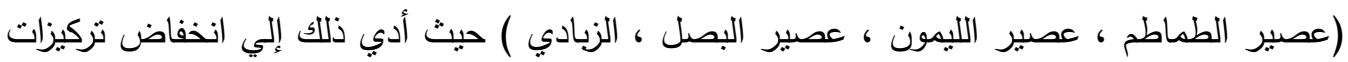

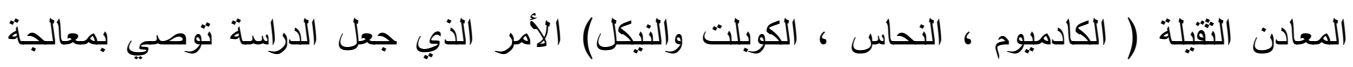
اللحوم الطازجة قبل طهيها بالأغذية الطبيعية محل الدراسة وذللك في محاولة للتخلص من التلوث

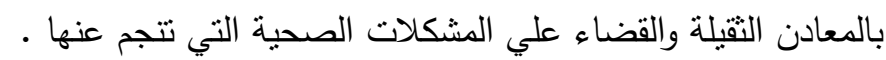

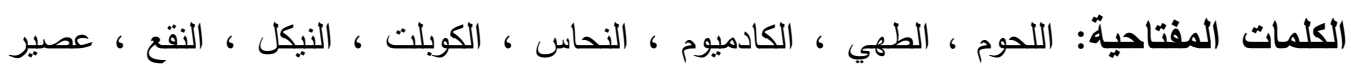
الطماطم ،عصير الليمون ،عصير البصل ،الزبادى. 